\title{
The Digital Role in Environmental Sustainability: Corporate Social Responsibility Disclosure Performance and Quality of Earnings
}

\author{
$\operatorname{Marsdenia}^{1 *}$ \\ ${ }^{1}$ Accounting and Auditing Laboratory, Vocational Education Program, Universitas Indonesia \\ *Email: idelid53@gmail.com
}

\begin{abstract}
This research explores several studies on the role of digital technology in environmental sustainability, corporate social responsibility performance (CSRP), and earnings quality. CSRP is expected to strengthen the quality of earnings in the financial statements of the company. This literature review analyzes studies that describe several related topics, such as the digital era, the role of the digital in environmental sustainability, CSRP, and the earnings quality in the financial reports. This work of research concludes that the digital era has a role to play in environmental sustainability and that CSRP should strengthen the quality of earnings in the financial statements. This research shows that companies with higher CSRP rank maintain their reputation, ensuring that their earnings report and financial statements are satisfactory. There are opportunities for future research on whether the result persists if either primary or secondary data are used as this work of research is a simple analysis of several published studies.
\end{abstract}

\section{Keywords: digital era, environmental, sustainability, CSRP (JEL format)}

\section{Introduction}

Currently, the rapid technological innovation of the digital era has forced us to anticipate changes in every aspect of our lives. The Industrial Marketing Management Review studied the effect of digital technology on markets, concluding that the more valuable the content, the more engaged the employer accounts, and the more likely they are to believe the service provider and share their positive thoughts about those products or services (Bai \& Chang, 2011). Actually, the concept of digital literacy was introduced in the early 1980s. Later, the broader concept of ICT literacy, including technical ICT skills, was brought to the attention of many researchers (Laar et al., 2017). According to Mazhelis, Waldburger, Machado, Stiller, and Tyrväinen (2013), for the organizations that manage these constrained devices, monitoring each device's operational status and performance level and accounting for their resource usage are very important. Their experiment indicated that the constrained applications protocol is fit for efficiently transferring monitoring and accounting data, both due to its small energy footprint and its memory-wise compact implementation.

Thus, it is important to broaden our knowledge of the determinants of firm engagement in environmental protection as part of a more general understanding of firm behavior with regard to Corporate Environmental Performance (CEP) (Laar et al., 2017). Environmental protection is part of Corporate Social Responsibility (CSR), and CSR practices are an organizational device leading to more effective use of resources, which, then, has a negative impact on earnings management practices. The ASTM (2004) reported that as environmental protection is part of CSR, CSR firms tend to be more conservative in accounting and operating decisions and provide more transparent financial information, and subcategories of KLD ratings provide distinct implications about firms' financial reporting practices. Hagos and Payton (2010) said that managers in an emerging economy manage earnings when they provide more CSR disclosures. Such earnings management is achieved through income-increasing discretionary accruals. Furthermore, companies in the export-oriented industries that are dominated by powerful stakeholders (international buyers) disclose more CSR activities; provide transparent financial reports through constraining earnings management; show environmental dynamism; and have higher ownership concentration and leverage (Hakim, 2017). CSR initiatives reduce transaction costs. We found that CSR is associated with improved access to financing in countries with weaker equity and credit markets; greater investment and lower default risk in countries with more limited business freedom; and longer trade credit periods and higher future sales growth in countries with weaker legal institutions. Our findings provide new insights into non-market mechanisms, such as CSR, through which firms can compensate for institutional voids (Ghoul et al., 2016).

Increased CSR disclosure and more readable CSR reports are associated with better CSR performance. Our findings suggest that extending CSR disclosure increases transparency regarding firms' social and 
environmental performance, whereas using less-readable language in CSR reports increases obfuscation. This study contributes to the disclosure literature by documenting that the complexity indices that have been used as measures of obfuscation in prior finance and accounting research can help shareholders, financial analysts, and investors determine the credibility of CSR disclosure. Hammel and Prahalad (1994) stated that the positive effects of CSR may be more pronounced in China. However, normative pressure to engage in socially responsible behavior may not be as strong in other emerging economies as it is in China. Thus, the impact of CSR activities on firm performance may show different patterns in other emerging economies (Bai \& Chang, 2011).

The research sample consists of all companies listed on the Indonesia Stock Exchange (IDX) in the miscellaneous industries sector for the period 2009-2013. There are 92 firm-years included in this study. CSR is measured by scoring CSR activities of a firm on the basis of the GRI Index guideline version 3.1, whereas the attribute of earning quality that is used in this study denotes accrual quality. We include two control variables in this research model, i.e., firm size and leverage. The results show that CSR performance do not explain the changes in accrual quality. Leverage also has no effect on accrual quality. However, firm size has a significant effect on CSR performance, while the sign of association is contrary to what was expected (Gilster, 1998).

Further, considering the CSR and auditing fields, there is an optimal level of CSR performance that minimizes the auditors' assessment of the risk of material misstatement, which, in turn, lowers the need for greater auditor effort, and which is why auditors charge firms significantly less when their CSR performance is at the optimal level. Finally, we also show that the optimal level of CSR performance varies with the degree (Kim, 2012). The result of regression analysis modeling with audit fee as its dependent variable shows that CSR and CGI have positive (+) coefficients, whereas we expected their signs to be negative $(-)$. According to the results, companies with excellent CSR and CGI pay higher audit fees, something that flies in the face of logical expectation. The reasons for this phenomenon are as follows: (1) the audit fee is determined without an auditor's investigation into a company's internal accounting and information systems, and (2) in the case of Korea, the companies that are excellent in CSR and CGI pay higher audit fees because of their higher financial standards, which require more auditors' efforts for a thorough audit. Companies that apply good corporate governance have a similar risk and scope of work.

In the context of Indonesia, audit firms always use an easy measurement for the audit fee offer, particularly for clients with good corporate governance, such as those in the research sample. Therefore, as an easy measurement, normally an audit fee offer provided by an audit firm refers to the asset size of clients (Firefree, 2012). Audit quality was found to be significantly related to audit fees and to have a positive relationship with the latter, which implies that the quality of an audit is dependent on the audit fee; the higher the audit fee the higher the quality and reliability of the audit work. To this end, this study concludes that audit quality and audit fee are positively significantly related (Firefree, 2012).

On the above, there is still a gap in the literature on the relationship of CSRP with quality of earnings, with some studies showed mixed results; thus, this paper tries to find evidence of moderating variables on the research equations. The moderating variable is Corporate Governance Score/Index (CGS). We hypothesized that the moderating variable strengthens the association of CSRP with CGS.

\section{Literature Review}

\section{Digital Literacy}

According to Gilster (1998), digital literacy is defined as the mindset to both easily and affectively access knowledge in different codes and formats (e.g., text, videos, and images) in the digital environment. In addition, Hagos and Payton (2010) concluded that digital literacy is regarded as an important ability for learning, participating, and contributing. Debate still rages on the general features of digital literacy, which consists of at least the following three aspects (Vooght, Exted, C, \& Mishra, 2013).

The first aspect is Operating Information Communication and Technology (ICT), which refers to "tool literacies," i.e., having the necessary skills to be able to use, operate, and solve technology-related problems, e.g., with word processors, spreadsheet programs, and navigation tools (Fraillon, Schultz, \& Ainley, 2013). The second aspect is working with information, which refers to the cognitive skills required to deal with the huge or massive scale of information available on the Internet in the "big data era." The third aspect refers to understanding the digital era, which is marked by extensive use of digital technology. On the basis of these three aspects of technology literacy, we can conclude that technology literacy is about not only technical skills but also multidisciplinary skills. 


\section{Environmental Protections and Corporate Social Responsibility Performance}

There are growing concerns regarding the business of companies with very low CSR disclosure quality. This condition motivated previous researchers to investigate the relationship between environmental disclosure and environmental performance. Our study showed that most research on CSRP employed environmental performance as an explanatory variable (independent variable). The literature does not present consistent conclusions. Although some prior research concluded that there is a relationship between environmental performance and environmental disclosure, other research findings did not.

\section{Earnings Quality}

Earnings quality is a very basic principle in accounting and financial economics. However, there are general disagreements regarding how to define and measure it. The list of candidate measures is very long: earnings persistence, predictability, asymmetric loss recognition, various forms of benchmark beating, smooth earnings, magnitude of accruals, income-increasing accruals, absolute value of discretionary or abnormal accruals, and the extent to which accruals map into cash flows. Archival research complicates the measurement of earnings quality and is unable to satisfactorily parse out the portion of managed earnings from the portion resulting from the principle of earnings process (Dechow, Ge, \& Schrand, 2010).

\section{Methods}

We collected data on this topic by reviewing literature matching the following topics: the digital era, sustainability report, corporate social responsibility performance (CSRP) and earnings quality. Subsequently, by analyzing the reviewed literature, this paper provides new insight regarding the role of the digital era in environmental sustainability as well as the role of CSRP in the quality of earnings presented in the financial statements.

\section{Results and Discussion}

The role of the digital era in environmental sustainability is marked by massive innovation in several aspects, which influences the protection of the environment. Currently, there are huge mining activities in some countries that lack the monitoring capabilities or the will to restore the Earth after mining activities cease.

Recently, many companies have begun to take great care to disclose CSR activities in the notes of their financial statements. CSR scoring is known as corporate social responsibility performance (CSRP). Actually, CSR consists of social activities and environmental protection activities. This study only focused on the environmental protection activities of company.

As we know, the digital era is marked by activities over the Internet, which is characterized by its being paperless, borderless, and without time limitations. This means that in the digital era, people from a distance can communicate with each other, particularly to continually protect the environment. For example, by using digital technology, we can map the areas of the Earth that are in a critical condition, e.g., where we should take emergency action to save the people and the Earth.

As environmental protection is part of CSR, firms utilizing CSR are more conservative in accounting and operating decision-making and provide more transparent financial information, with subcategories of KLD ratings providing distinct implications regarding firms' financial reporting practices. This means that, companies that voluntarily allocate their funds to environmental activities are more likely to provide high-quality financial statements, which present the synergy between fund allocation to the environment and the high rank of environmental performance. Thus, the company continues to exhibit high performance in terms of environmentally sound practices.

\section{Conclusions}

Hopefully, in the future, the digital era can play an important role in environmental sustainability. Environmental sustainability is determined by the CSRP of a company, which is described by a score and based on the company's environmental activities, such as explaining to society the importance of taking care of the environment around them or exhorting them toward enlisting their services in saving the world so that it continues to provide prosperity to its people. 
In the correlation between CSRP and quality of earnings, we show that CSRP mirrors the corporate image and attracts new investors in the business of a company. Thus, each company benefits by spending their money on environmental protection and/or environmental activities.

\section{References}

ASTM E1529-06 (2004). Standard test methods for determining effects of large hydrocarbon pool fires on structural members and assemblies. West Conshohocken (PA): ASTM International.

Bai, \& Chang (2011). Corporate Social Responsibility and Firms Performance: mediating Role of Marketing Comoetence and the Moderating role of Market Environment. Asia Pacific Journal of Management, 32, 505-530.

Dechow, P., Ge, W., \& Schrand, C. (2010). Understanding earnings quality: a review of the proxies, their determinants and their consequences. Journal of Accounting and Economics, 50(2-3), 344-401. https://doi.org/10.1016/j.jacceco.2010.09.001.

Firefree Coatings, Inc. (2012). FF88 Intumescent. Water-based coating for building materials. Retrieved from http://www.firefree.com/fire-retardant-products/ff88-intumescent-coating.php.

Fraillon, J., Schultz, W., \& Ainley, J. (2013). International computer and information literacy study assessment framework, Amsterdam JEA.

Ghoul, Guedhami, \& Kim, D. Country-level institutions, Firm Value, and the Role of Intiative. Journal of International Business Study 2016;22:1-26.

Gilster, F. (1998). Digital literacy. New York: John Wiley \& Sons.

Hagos, C., \& Payton, S. (2010). Digital literacy Across curriculum.

Hakim (2017). European journal of accounting. Auditing and Finance Research, 5(1), 6-17.

Hammel, G., \& Prahalad,C. K. (1994). Competing for the future.Boston, MA : Harvard Business School Press.

Kim (2012). Park and Wier. Is earnings Quality associations with corporate social responsility? The Accounting Review, 87(3), 761-796.

Mazhelis, O., Waldburger, M., Machado, G. S., Stiller, B., \& Tyrväinen, P. (2013). Retrieving monitoring and accounting information from constrained devices in internet-of-things applications. Lecture Notes in Computer Science, 136147. https://doi.org/10.1007/978-3-642-38998-6_17.

Vaan Laar, E., Van Deursen, A., Van Dijk, J., \& de Haan, J. (2017). The Relation between 21st century skills and digital skills: A Systematic Literatur review. Review Computers in Human Behavior, 24(3), 623-648.

Vivek, S. D., Beatty, S. E., Morgan, R. M., \& M. (2012). Customer engangements : exploring customer realtionships beyond purchase. Journal of Marketing Theory and Practice, 20(2), 122-146. https://doi.org/10.2753/MTP10696679200201.

Vooght, J., Exted, O. D., C., \& Mishra, P. (2013).Challenges to learning and Schoolimg in the Digital Networked World of the 21 st century. Journal of the Computer Assisted Learnings, 29, 403-413. 